\title{
Impact of multidisciplinary therapy on the functioning of children with autism. Results of the "Supporting the development of children with autism" project using the ATEC form
}

\section{Wpływ multidyscyplinarnej terapii na funkcjonowanie dzieci $z$ autyzmem. Wyniki projektu „Wspomaganie rozwoju dzieci $z$ autyzmem" $z$ wykorzystaniem formularza ATEC}

\author{
Piotr Sobaniec ${ }^{1,3}$, Barbara Szukiel2,3, Ewelina Batruch ${ }^{1,3}$, Urszula Kruk ${ }^{3}$, Joanna Łotowska ${ }^{4}$ \\ ${ }^{1}$ Neuromaster - Institute of Neurophysiology, Gliniana 14 Str., 15-068 Białystok, Poland \\ ${ }^{2}$ Department of Pediatric Neurology and Rehabilitation, Medical University of Białystok, Waszyngtona 17 Str., 15-274 Białystok, \\ Poland \\ 3 "Hope and Opportunity" Foundation, Gliniana 14 Str., 15-068 Białystok, Poland \\ ${ }^{4}$ Department of Medical Pathomorphology, Medical University of Białystok, Waszyngtona 13 Str., 15-269 Białystok, Poland \\ DOI:10.20966/chn.2017.53.408
}

\section{ABSTRACT}

The multitude and variety of Autism Spectrum Disorders require multidisciplinary diagnosis and therapy. The Department of Pediatric Neurology and Rehabilitation at the Medical University of Bialystok is an example of a center guided by the principle of multidisciplinary cooperation, which resulted in over 250 diagnosed autism cases in 2005-2015.

The study group included 35 children ( 32 boys and 3 girls aged 5-11 years) diagnosed with ASD and participated in subsequent editions of the "Supporting the Development of Children with Autism" program. Each participant was assigned 105 hours of therapy, including 45 hours of neurofeedback, 20 hours of speech therapy, 20 hours of pedagogical therapy and 20 hours of hippotherapy. To assess the level of functioning we used The Autism Treatment Evaluation Checklist (ATEC). Parents or guardians completed it twice: prior to therapy and after the completion of the project.

Improved communication skills were reported in 29 out of 35 children. Progress in social functioning was noticeable in 32 subjects. A total of 33 patients achieved better results in 'Sensory/cognitive awareness' and 'Health/ physical/ behavior' categories.

Holistic therapy in children with autism resulted in an improvement in functioning and is crucial due to the complex picture of the disorder. ATEC can be a useful tool for the diagnosis and assessment of progress made by children with ASD undergoing therapy.

Keywords: autism, ASD, ATEC, neurofeedback, speech therapy, effectiveness, multidisciplinary therapy
STRESZCZENIE

Różnorodność całościowych zaburzeń rozwoju wg ICD-10 tj. zaburzeń ze spektrum autyzmu (ASD) wg DSM-5 wymaga multidyscyplinarnej i holistycznej diagnostyki oraz terapii. W Klinice Neurologii i Rehabilitacji Dziecięcej w Białymstoku w latach 2005-2015 opieką objęto ponad 250 dzieci.

Niniejsze opracowanie dotyczy wybranej grupy 35 pacjentów (32 chłopców, 3 dziewcząt, w wieku 5-11lat) z rozpoznaniem ASD, którzy uczestniczyli w realizacji programu „Wspomaganie rozwoju dzieci z autyzmem" prowadzonego przez Fundację "Nadzieja i Szansa” w Białymstoku.

Każdy pacjent uczestniczył w 105 godzinach terapii, zawierających 45 godz. z EEG biofeedback (Neurofeedback), 20 godz. logopedycznych, 20 godz. zajęć pedagogiczno-psychologicznych, 20 godz. hipoterapeutyczno-sensorycznych.

Zaburzenia funkcjonowania oraz wpływ terapii oceniono dwukrotnie - przed i po terapii, z wykorzystaniem kwestionariusza ATEC (Autism Treatment Evaluation Checklist) wypełnionego przez rodziców. Istotna poprawę w zakresie umiejętności komunikacji interpersonalnej uzyskano u 29 podopiecznych, poprawę funkcjonowania społecznego odnotowano u 32 przypadków, u 33 dzieci wykazano poprawę w zakresie świadomości poznawczej, zachowania i zdrowia fizycznego. Uzyskane opinie były zgodne z obserwacjami terapeutów.

W wyniku zastosowanego programu terapeutycznego uzyskano liczącą się poprawę $\mathrm{w}$ zakresie funkcjonowania i kontaktów społecznych dzieci objętych opieką. Wykorzystanie kwestionariusza ATEC potwierdza możliwość jego zastosowania jako narzędzia badawczego do oceny funkcjonowania, stopnia zaburzenia oraz wpływu terapii u pacjentów ze spektrum autyzmu. Słowa kluczowe: autyzm, ASD, ATEC, neurofeedback, terapia logopedyczna, skuteczność, terapia multidyscyplinarna

\section{INTRODUCTION}

Pervasive developmental disorders (PDD) (which include autism) are diagnosed in Poland based on criteria developed by the World Health Organization (WHO) and contained in the ICD-10 Classification. Changes in the diagnostic process that will occur after the introduction of 
ICD-11 are not yet known [1]. It is assumed, based on the compatibility of the current editions of the European and US classifications, that the proposed changes will also be consistent. In May 2013, the DSM-5 Classification, in which the term PDD was replaced with "Autism Spectrum Disorders," was implemented by the American Psychiatric Association [2, 3]. Two groups of symptoms from the previous diagnostic triad, i.e. impaired social interaction and impaired communication, were combined into one category - social communication. Although the different classifications are regularly modified and updated, they still assume the necessary coexistence of three impairments defined by Lorn Wing, such as impaired communication, social interaction and the occurrence of particular patterns of behavior [4, 5].

The multitude and variety of disorders require multidisciplinary diagnosis and therapy $[6,7]$. Our Department of Pediatric Neurology and Rehabilitation at the Medical University of Bialystok is an example of a center guided by the principle of interdisciplinary cooperation which resulted in over 250 diagnosed autism cases in 2005-2015. This has allowed us to gain a large group of patients, experience as well as to implement therapies that resulted in a longterm research and therapeutic project known as "Supporting the development of children with autism" organized by our Department and the "Hope and Opportunity" Foundation in Białystok. The patient has become the element that brings together specialists from various fields, and thus the center of common interest, which significantly increased therapeutic effectiveness [8-10].

Since 2009 a comprehensive therapeutic program for children with autism and their families has been organized every year. The program assumes a holistic approach to patients. Participants of the therapy first undergo clinical diagnosis in our center. The project begins and ends with a functional diagnosis, performed by a team of specialists: pediatric neurologist, psychologist, educator, speech therapist, and physiotherapist. The diagnostic process is multistage. It involves documentation analysis, interviewing parents, observation of the child in natural and arranged situations as well as specialist physical examinations. The collected results enable determining individual rehabilitation and therapeutic programs which involve speech therapy, pedagogical therapy, neurofeedback (EEG-biofeedback)and equine-assisted therapy (hippotherapy). Motivating parents to actively support their children is an important element of the program. This is achieved by organizing integration meetings, specialist consultations, and the pedagogization of parents. Pharmacological treatment may be used in justified cases.

\section{METHODOLOGY}

So far, a total of 35 patients participated in subsequent editions of the "Supporting the development of children with autism" program. There were 32 boys and 3 girls aged 5-11 years, $(\operatorname{avg}=7.5 ; \mathrm{SD}=6.66)$. Each participant was assigned 105 hours of therapy, including 45 hours of neurofeedback, 20 hours of speech therapy, 20 hours of pedagogical therapy and 20 hours of hippotherapy.
1.1. Neurofeedback is a neurophysiologic rehabilitation method using the registration and modulation of a patient's bioelectric EEG activity. The aim of the exercises is to improve central nervous system functioning by normalization of impaired EEG [11]. The achieved changes in behavior include an improvement in verbal and non-verbal communication, concentration, emotion control and social contacts [12, 13]. Therapy included 45 neurofeedback sessions for each child with each session lasting 60 minutes. Training parameters were tailored to each patient based on quantitative QEEG analysis, and the results were compared with normative databases $[14,15]$.

1.2. Furthermore, the children participated in speech therapy (20 hours per child). Although all participants used verbal speech, they showed different levels of communication functioning. Therefore, speech therapy was aimed not only at improving articulation organ function, speech clarity or correcting speech impediments, but also at developing skills that are crucial for communication, such as response to commands, the ability to look with attention and focus on the speaker. The main objective was to develop speech understanding, stimulate spontaneous vocalization, arrange communication-promoting situations, and increase passive and active vocabulary resources [16]. Special attention was paid to the development of pragmatic efficiency, i.e. the ability to achieve an intended goal, to develop the ability of understanding and using metalinguistic elements.

1.3. Pedagogical therapy was another type of therapy proposed in the project. It aimed to develop social and cognitive skills through the acquisition of knowledge by a child to the best of their abilities [17]. Based on an analysis of functioning in different areas, a program considering the strong points and the individual needs of each patient was developed. Sessions were conducted individually; each child took part in 20 sessions. After each meeting parents were informed on the course of each session as well as the progress and difficulties experienced by their child. They also had a chance to see the arts and crafts created by their child and received guidance for further work at home.

1.4. Furthermore, the participants took part in a cycle of 20 sessions of hippotherapy, which is a form of psychomotor rehabilitation. It aims to improve sensory awareness, balance, coordination, sense of rhythm as well as body-scheme and spatial orientation [18].

\section{ATEC FORM:}

The Autism Treatment Evaluation Checklist (ATEC) was used to assess the level of functioning or deficits (Table I) [19]. Parents or guardians completed it twice - the initial assessment was performed prior to therapy, while the summarizing assessment was performed after the completion of the project.

The questionnaire evaluates four different spheres of functioning. 
Table I. The ATEC form [19]

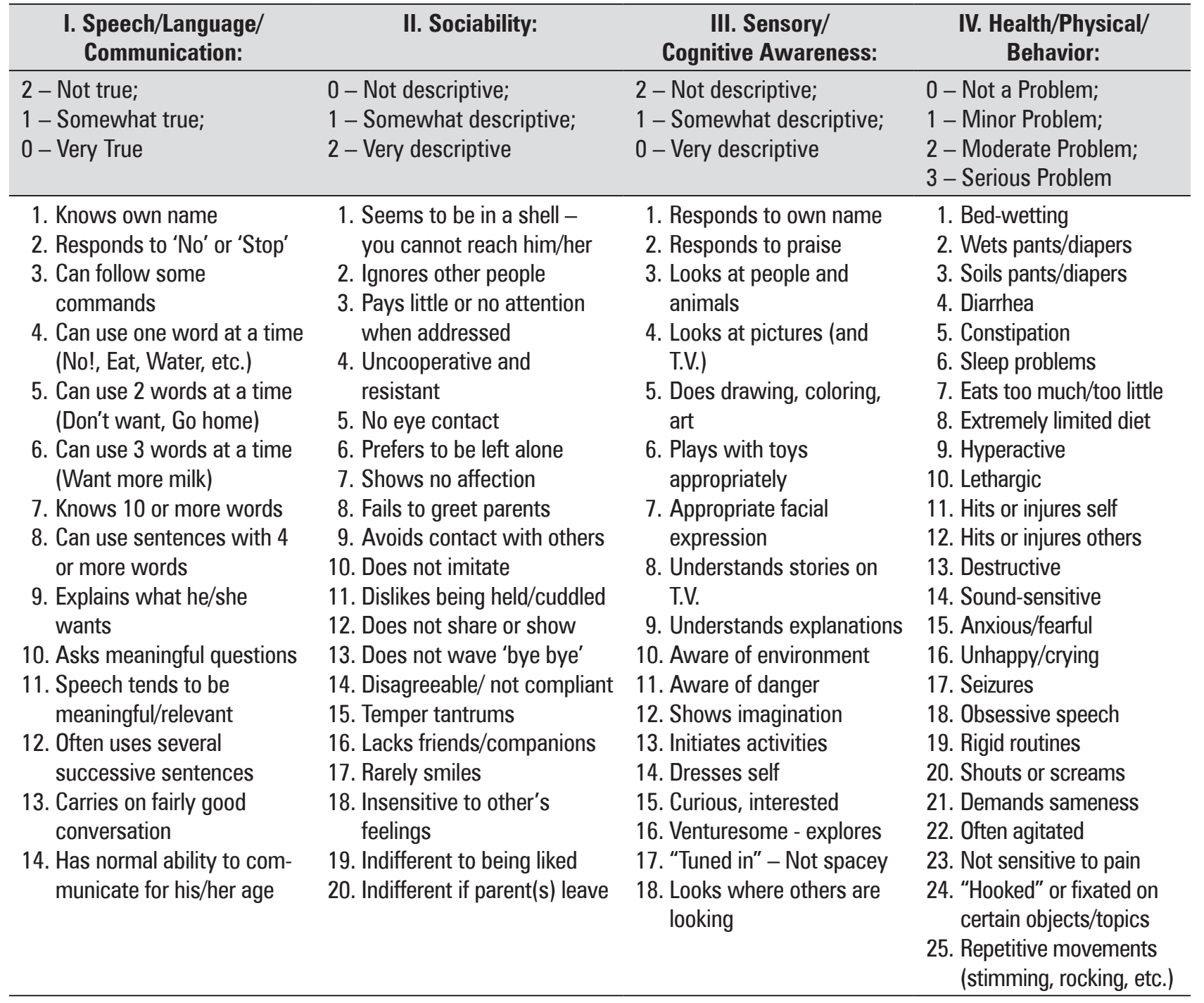

It can be analyzed as a whole or in terms of categories. The total maximum score in the above mentioned categories is 179. A higher score indicates more severe disorders. A score of 0 or very low scores indicate normal development. The score is converted into percentiles, which classify the patient into one of three groups varying in the degree of autistic severity [20,21].

\section{STATISTICAL ANALYSIS}

To calculate statistical significance of differences between ATEC results, we used the t-Student test. A level of $\mathrm{p}<0.05$ was considered statistically significant. PQStat software was used for calculations.

\section{RESULIS AND DISCUSSION}

The ATEC findings are presented in Table II.

There was a change of 17.26 points in the mean posttherapeutic ATEC score for the whole group. The greatest change was observed in Category IV health/physical/ behavior with a decrease in the mean value from 17.37 to 11.2. The minimum value dropped by 15 points, and the maximum value dropped by 13 points. The median decreased from 45 to 31 points. All descriptive statistics pa- rameters shown in Table II indicate improvement in the functioning of the evaluated children.

Improved communication skills were reported in 29 out of 35 children; 6 children showed no changes, as reported by their parents. Progress in social functioning was noticeable in 32 subjects; the results of 2 patients did not differ from baseline; deterioration was observed in one case. A total of 33 patients achieved better results in category III. Sensory/ Cognitive Awareness and IV. Health/ Physical/ Behavior. (Error: Reference source not found).

The ATEC results categorize children into three groups according to their level of functioning [19]:

- Up to 19 percentile ATEC $<9$ fare better, Behavior more or less normal, able to carry out two-way conversation.

- Level between 20 and 79 percentiles. Child may lead semi-independent life.

- Level greater than 80 percentile. Severely autistic.

Data obtained before therapy (Table III) indicate that 21 patients achieved results placing them in the high-functioning group, while 14 patients were classified into the semi-independent group. After completion of the project the results indicated an improvement (reduced symptoms), 
Table II. ATEC findings before and after therapy. $\mathrm{N}=35$

\begin{tabular}{|c|c|c|c|c|c|c|c|c|c|c|}
\hline PRE & POST & & & & & & & & & \\
\hline & I & II & III & IV & Total & I & II & III & IV & Total \\
\hline Median & 9 & 10 & 9 & 18 & 45 & 5 & 6 & 6 & 11 & 31 \\
\hline AVG & 10.25 & 10.2 & 9.94 & 17.37 & 47.77 & 6.52 & 6.68 & 6.08 & 11.2 & 30.51 \\
\hline SD & 5.20 & 5.01 & 4.56 & 9.30 & 17.82 & 5.22 & 4.13 & 4.19 & 6.99 & 15.83 \\
\hline Minimum & 1 & 2 & 2 & 3 & 24 & 0 & 0 & 0 & 0 & 9 \\
\hline Maximum & 21 & 22 & 19 & 40 & 90 & 21 & 18 & 15 & 27 & 77 \\
\hline Variance & 27.07 & 25.16 & 20.82 & 86.53 & 317.76 & 27.25 & 17.10 & 17.61 & 48.92 & 250.90 \\
\hline
\end{tabular}

Table III. Percentile distribution of participants before and after therapy according to ATEC data

\begin{tabular}{|c|c|c|c|c|}
\hline Percentile & ATEC score & Pre (n) & Post(n) & \multirow{12}{*}{$\begin{array}{l}\text { - eight persons changed from } 2 \text {. to } 1 \text {. } \\
\text { - one person changed from } 3 \text {. to } 1 \text {. } \\
\text { - four persons changed from } 3 \text {. to } 2 \text {. } \\
\text { - one person changed from } 4 \text {. to } 1 \text {. } \\
\text { - two persons changed from } 4 \text {. to } 2 \text {. } \\
\text { - one person changed from } 4 \text {. to } 3 \text {. } \\
\text { - one person changed from } 5 \text {. to } 1 \text {. } \\
\text { - one person changed from } 5 \text {. to } 2 \text {. } \\
\text { - one person changed from } 5 \text {. to } 4 \text {. } \\
\text { - one person changed from } 6 \text {. to } 2 \text {. } \\
\text { - one person changed from } 6 \text {. to } 3 \text {. } \\
\text { - one person changed from } 7 \text {. to } 2 \text {. } \\
\text { - one person changed from } 7 \text {. to } 5 \text {. } \\
\text { - one person changed from } 8 \text {. to } 2 \text {. } \\
\text { - one person changed from } 9 . \text { to } 7 \text {. } \\
\text { - ten persons with no change }\end{array}$} \\
\hline 1. Mild autism & $0-30$ & 6 & 17 & \\
\hline 2. $0-9$ & $31-41$ & 10 & 12 & \\
\hline 3. $10-19$ & $42-50$ & 5 & 2 & \\
\hline 4. $20-29$ & $51-57$ & 5 & 2 & \\
\hline 5. $30-39$ & $58-64$ & 3 & 1 & \\
\hline 6. $40-49$ & $65-71$ & 2 & 0 & \\
\hline 7. $50-59$ & $72-79$ & 2 & 1 & \\
\hline 8. $60-69$ & $80-89$ & 1 & 0 & \\
\hline 9. $70-79$ & 90-103 & 1 & 0 & \\
\hline 10. $80-89$ & 104-179 & 0 & 0 & \\
\hline $\begin{array}{l}\text { 11. 90-99 } \\
\text { Severe autism }\end{array}$ & 180 & 0 & 0 & \\
\hline
\end{tabular}

which, in the global percentile assessment, qualifies 31 patients to the first group.

Overall ATEC evaluation (Error: Reference source not found) showed reduced scores after the implemented holistic therapy. A reduced scatter of results was noticeable, indicating that the group became more homogeneous in terms of level of functioning in all investigated areas. The differences were statistically significant $(p=0.00006)$ indicating the efficacy of therapy.

This was followed by an analysis of results in different categories to determine in which areas the changes occurred.

Assessment of speech, linguistic skills, and level of communicative functioning showed a mean improvement of 3.73 ATEC points, and the differences were statistically significant $(\mathrm{p}=0.003)$. (Error: Reference source not found).

The obtained results indicate improved Sociability in children participating in the program $(p=0.002)$ (Error: Reference source not found). The mean score for the whole group decreased by 3.52 points (Pre=10.2 Post=6.68). Thirty-two parents noticed improved social relationships in their children; the parents of two children did not report any improvement in social functioning. A reduction in the maximum values was observed in the study group, with an initial maximum score of 22 points, and 18 points after program completion. These changes were statistically significant.
Symptom reduction was also observed in Category III. Sensory/Cognitive Awareness. (Error: Reference source not found). Changes in scores after the therapeutic program were statistically significant $(\mathrm{p}=0.0004)$.

Parents reported the highest improvement in Category IV. Health/Physical/Behavior. (Error: Reference source not found). The mean score for the whole group decreased by 6.17 points. After therapy, the distribution of results was more homogeneous. The reduction was statistically significant $(\mathrm{p}=0.002)$.

\section{DISCUSSION}

The clinical picture of autism is very complex. Symptoms occur in many areas of a child's functioning. Children display impaired social relationships and communication skills as well as stereotyped behavior. These symptoms are related to each other; their severity and timing vary. Therefore, such a child should receive specialist therapy, including a diagnosis that would identify the needs and difficulties requiring therapeutic focus. And finally, a holistic therapeutic and rehabilitation program should be developed and implemented [7]. A very important partner in the therapeutic process is the parent, who not only provides information about the child but also continues the work with them at home. Therefore, the education of parents is crucial. After each session, parents/guardians participat- 
ing in our project were informed about its course, progress made by their child, and received guidance on how to consolidate the acquired skills. They were also recommended specialist literature and training courses to broaden their knowledge on treatment [22].

The main drawback of combined therapy was the difficulty of assessing which interventions affected the patient and to what extent. A review of the literature describing holistic therapies for autism spectrum disorders did not reveal any studies using our research methods. The ATEC had been used in a small number of studies assessing the efficacy of therapeutic methods used alone. That is the reason we selected this tool for use in our research.

An improvement in speech, language, and communication skills was achieved in 29 children participating in our study. There was a decrease in the mean ATEC score from 10.25 to 6.52 , which was statistically significant. Magiati et al. described a decrease from 14.7 to 12.6 points after 5 years of multidirectional therapy [23]. The most common deficits reported by parents participating in our study included difficulties in understanding multi-stage commands, poor active and passive vocabulary, grammatically incorrect speech, echolalia, and pronoun reversal. The following pragmatic language skills were impaired: dialog, following the topic of conversation, adjusting the form of communication to the recipient. Sarah Al Shirian mentioned asking meaningful questions, having conversations as well as using meaningful and adequate speech as the biggest problems related to speech [24]. Batool and Ijaz confirmed, by achieving an improvement in skills, that the use of speech therapy as one of various therapeutic forms on children with autism is justified [25].

Jarusiewicz assessed the effects of neurofeedback therapy, achieving significant improvement in speech and communication skills, with a $29 \%$ reduction in the ATEC score [12]. Therefore, a speech therapist as well as other specialists participating in our study, which was developed in accordance with the selected form of holistic therapy, worked to improve the selected skills, and thus, achieved better effects.

Frequent problems in communication prevent establishing and maintaining social contacts. Lovaas referred to limited eye contact, lack of cooperation, becoming withdrawn, inadequate responses, and temper tantrums as the greatest social barriers in children with autism [26].

Sarah Al Shirian estimated the generally understood social integration of children with ASD as poor. Lack of friends was common and $66 \%$ of the described children did not like being hugged [24]. This was confirmed in our studies by parents who completed the second category of the ATEC. The average score was 10.2 prior to therapy and decreased by 3.52 , showing statistical significance. By the end of the program we achieved the greatest progress in initiating and maintaining eye contact, developing jointattention behavior and improved cooperation of children with therapists. The possibility of working on specific deficits with the assistance of many specialists helped the children generalize the desired behaviors and skills outside the artificially created situations. Examples of consolidated skills that were later used for social contacts at home and school included social smile, non-verbal communication during a casual conversation, use of courtesy forms and expressions as well as shared attention.

Al Shirian and Al Dera showed that social situations also reveal cognitive disorders, e.g. attention disorders, and impaired processing of stimuli associated with social information. Only $8 \%$ of children looked in the same direction as others [24].

Geier, Kern et al. suggested that health problems and behavior also hinder the functioning of children [27]. These aspects were analyzed in subscales III and IV of the ATEC evaluation performed on our patients. After completing the project, a statistically significant improvement was observed in the functioning of children in both these areas. The mean score in cognitive/sensory awareness was 9.94 before the sessions, and 6.08 after therapy. Similar results were obtained by Jarusiewicz, who reported an improvement in 17\% of children (based on the ATEC) after neurofeedback sessions [12]. The mean score related to health, physical development and behavior decreased by 6.17 points, which was the highest of all the analyzed categories.

All these dysfunctions are related to each other; they overlap and can lead to further difficulties. A thorough and accurate assessment of a child's current level of functioning and determination of the main therapeutic directions are necessary for the development of an effective rehabilitation and therapeutic program. It is therefore necessary to use multidirectional and holistic therapy. Such an approach ensures the best and most effective therapy, thus allowing for better functioning and development of children with autism. Focusing on the set goals and their implementation by each specialist using the methods and forms of work corresponding to their specialty is the most important element of interdisciplinary collaboration.

The ATEC, which assesses four areas of a child's functioning, may be used to evaluate progress made by a child undergoing therapy. It is a simple tool enabling to detect changes in the development of speech, communication, social integration, sensory impairment or behavior in a child with ASD. This was demonstrated and confirmed in the present study, which, due to the study group's small size, is of a preliminary nature and will be continued. The achieved improvement was further confirmed by an extensive quantative EEG analysis, which showed reduced QEEG amplitude coefficients: Theta/Beta, Theta/SMR, Theta/Alpha Theta/wide Beta, and increased dominant frequency, which had an impact on improved range of active speech, social interactions and behaviors.

\section{CONCLUSIONS}

The interdisciplinary therapy we used resulted in a significant improvement.

Holistic therapy in children with autism resulted in an improvement in functioning and is crucial due to the disorder's complex picture.

ATEC can be a useful tool for the diagnosis and assessment of progress made by children with ASD undergoing therapy. 


\section{COMPLIANCE WITH ETHICAL STANDARDS \\ Conflict of Interest:}

Author Piotr Sobaniec ${ }^{1,3}$ declares that he has no conflict of interest.

Author Barbara Szukiel ${ }^{2,3}$ declares that she has no conflict of interest.

Author Ewelina Batruch ${ }^{1,3}$ declares that she has no conflict of interest.

Author Urszula Kruk ${ }^{3}$ declares that she has no conflict of interest.

Author Joanna Łotowska ${ }^{4}$ declares that she has no conflict of interest.

\section{Ethical approval:}

All procedures performed in studies involving human participants were in accordance with the ethical standards of the institutional and/or national research committee and with the 1964 Helsinki declaration and its later amendments or comparable ethical standards. The Bioethics Committee of the Medical University of Bialystok approved the study.

\section{Informed consent:}

Informed consent was obtained from all individual participants included in the study.

\section{FIGURES}
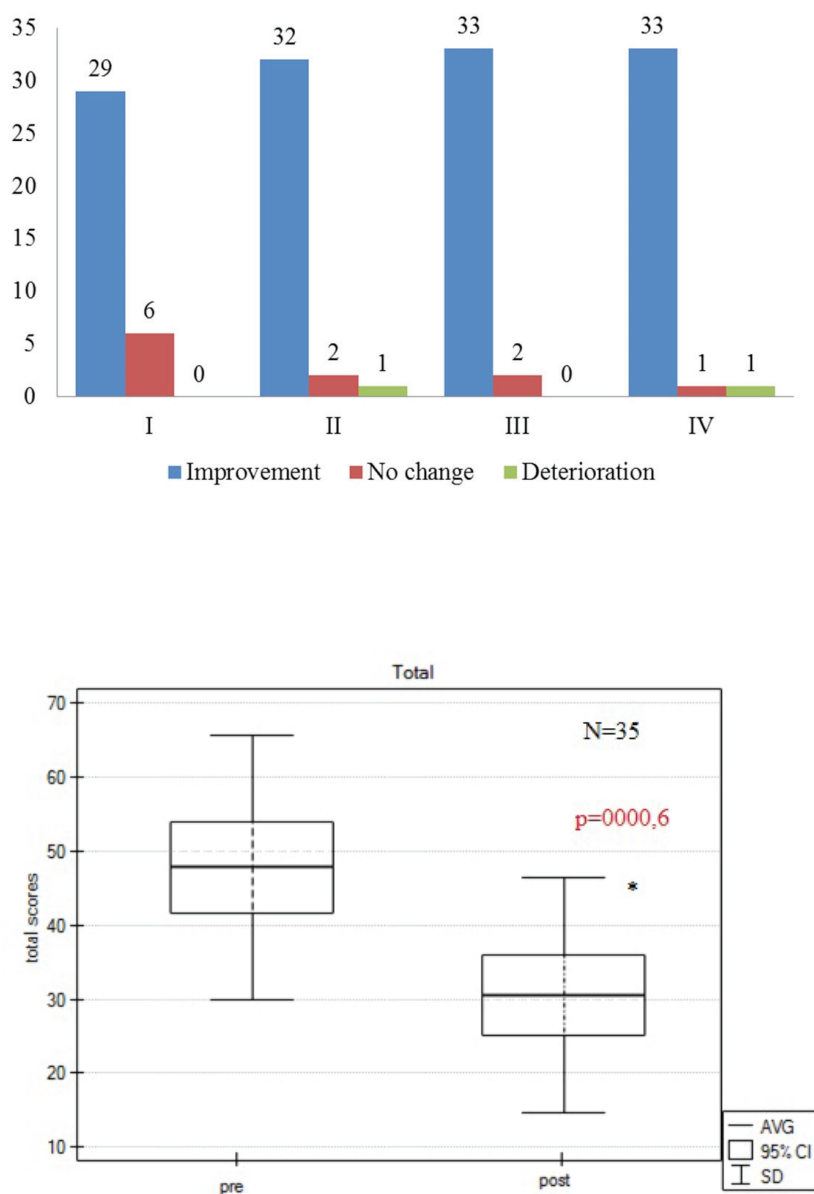
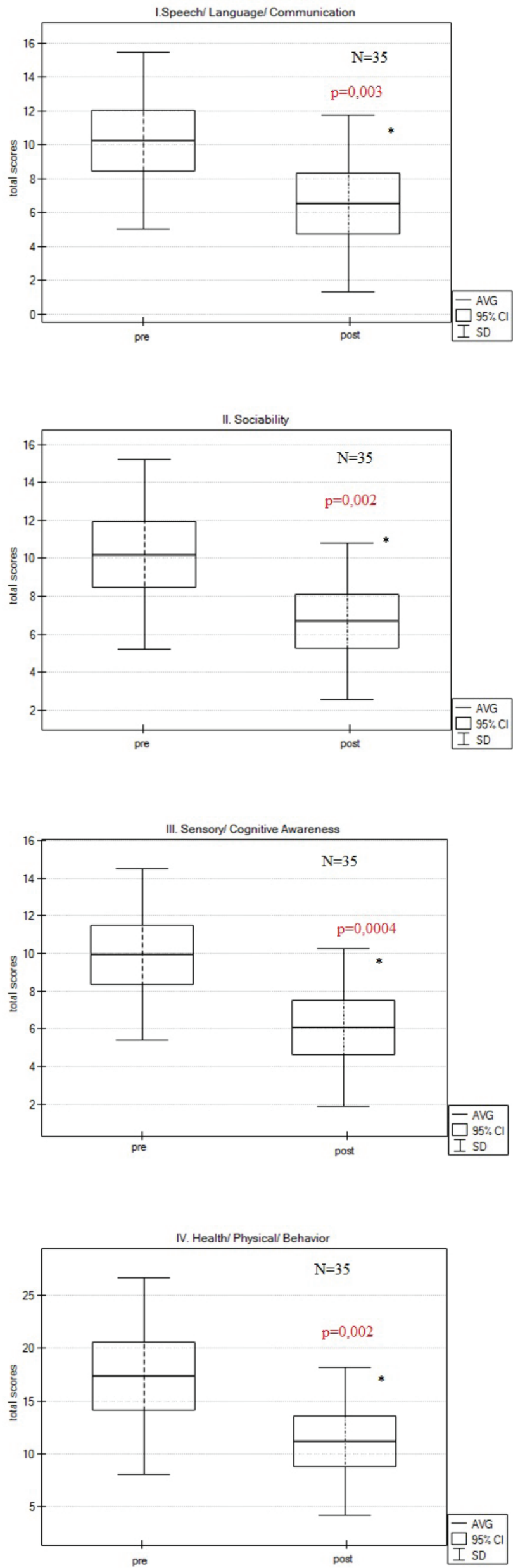


\section{BIBLIOGRAPHY}

[1] Heitzman J., Loza B., Kosmowski W.: Classification of mental disorders-a conceptual framework for the ICD-11]. Psychiatr Pol 2011; 45(6): 941 950.

[2] Kurita H., How to deal with the transition from Pervasive Developmental Disorders in DSM-IV to Autism Spectrum Disorder in DSM-V. Psychiatry Clin Neurosci 2011; 65(7): 609-610.

[3] Sharma N., Mishra R., Mishra D.: The Fifth Edition of Diagnostic and Statistical Manual of Mental Disorders (DSM-5): What is New for the Pediatrician. India Pediatr 2015; 52: 141-143.

[4] McCrimmon A., Rostad K.: Test review: autism diagnostic observation schedule, (ADOS-2) manual (part II): toddler module. Journal of Psychoeducational Assessment 2014; 32(1): 88-92.

[5] Wing L., Gould J.: Severe impairments of social interaction and associated abnormalities in children: Epidemiology and classification. Journal of autism and developmental disorders 1979; 9(1):11-29.

[6] Bobkowicz-Lewartowska L.: Wielowymiarowość zjawiska autyzmu dziecięcego. W poszukiwaniu metod terapii. Psychologia Rozwojowa 2005; 10(3).

[7] Was A., Sobaniec P., Kiryluk B., et al.: Czy to autyzm? Trudności w diag nozie. Neurol Dziec 2011; 41: 105-110.

[8] Jaklewicz H.: Całościowe zaburzenia rozwojowe. Psychiatria dzieci i młodzieży [Child and Adolescent Psychiatry], 2004; 110-128.

[9] Olchowik B., Otapowicz D., Waś A., et al.: Klinika Neurologii i Rehabilitacji Dziecięcej jako przykład współpracy interdyscyplinarnej. Neurol Dziec 2011; 20(41): 159-162.

[10] Pisula E.: Małe dziecko z autyzmem. 2005: Gdańskie Wydawnictwo Psychologiczne.

[11] Sobaniec P., Thompson L., Thompson M., et al.: Neurofeedback as an aid in the treatment and rehabilitation of selected neurological disorders. Neurol Dziec, 2014; 23(47): 41-50.

[12] Jarusiewicz B.: Efficacy of neurofeedback for children in the autistic spectrum: A pilot study. Journal of Neurotherapy 2002; 6(4): 39-49.

[13] Thompson M., Thompson L.: The Neurofeedback Book: An Introduction to Basic Concepts in Applied Psychophysiology. 2003: Association for Applied Psychophysiology and Biofeedback.

[14] Coben R., Linden M.,Myers T.E.: Neurofeedback for autistic spectrum disorder: a review of the literature. Appl Psychophysiol Biofeedback 2010; 35(1): 83-105.
[15] Coben R., Mohammad-Rezazadeh I.,Cannon R.L.: Using quantitative and analytic EEG methods in the understanding of connectivity in autism spectrum disorders: a theory of mixed over- and under-connectivity. Front Hum Neurosci 2014. 8: 45

[16] Lewis A., Rudd C.J., Mills B.: Working with children with autism: an interprofessional simulation-based tutorial for speech pathology and occupational therapy students. J Interprof Care 2017; 32(2): 242-244.

[17] Otapowicz D., Cholewa M., Marchlewska A., et al.: Świetlica szpitalna jako miejsce oddziaływań terapeutycznych. Neurol Dziec 2011; 20(41): 153-157.

[18] Steiner H.,Kertesz Z.: Effects of therapeutic horse riding on gait cycle parameters and some aspects of behavior of children with autism. Acta Physiologica Hungarica, 2015; 102(3): 324-335.

[19] Rimland B., Edelson S.M.: Autism treatment evaluation checklist (ATEC). Retrieved October 2000; 23: 2006.

[20] Cohen D.J.,Volkmar F.R.: Handbook of autism and pervasive developmental disorders. 4th ed. 2014: John Wiley \& Sons Inc.

[21] Accardo P. and Bostwick H.: Zebras in the living room: the changing faces of autism. J Pediatr 1999; 135(5): 533-535.

[22] Bokus B.: Niedyrektywna terapia zabawowa. Koncepcja V.M.Axline. Psychologia Wychowawcza 1979; 5: 673-688.

[23] Magiati I., Moss J., Yates R., et al.: Is the Autism Treatment Evaluation Checklist a useful tool for monitoring progress in children with autism spectrum disorders? J Intellect Disabil Res 2011; 55(3): 302-312.

[24] Al Shirian S., Dera H. Al.: Descriptive characteristics of children with autism at Autism Treatment Center, KSA. Physiol Behav 1999; 151: 604608

[25] Batool I., ljaz A.: Effectiveness of Speech and Language therapy for Autism Spectrum Disorder. Journal of Pakistan Psychiatric Society 2015; 12(1).

[26] Lovaas 0.I., Smith T.: A comprehensive behavioral theory of autistic children: paradigm for research and treatment. J Behav Ther Exp Psychiatry 1989; 20(1): 17-29.

[27] Geier D.A., Kern J.K., Geier M.R.: A prospective Cross-sectional Cohort Assessment of Health, Physical, and Behavioral Problems in Autism Spectrum Disorders. Maedica (Buchar) 2012; 7(3): 193-200. 
